\title{
Expression of basic fibroblast growth factor in intact and ulcerated human gastric mucosa
}

\author{
M A Hull, J L Brough, D G Powe, G I Carter, D Jenkins, C J Hawkey
}

\begin{abstract}
Background-Basic fibroblast growth factor (bFGF) promotes angiogenesis and healing of gastric ulcers in rats, and bFGF expression is up regulated in such ulcers. However, little is known about expression of bFGF in human gastric mucosa.

Aims-To investigate bFGF expression in intact human gastric mucosa and gastric ulcers and to determine whether low bFGF content or altered binding by mucosa is associated with ulceration.

Subjects-Endoscopy outpatients, gastrectomy patients, and organ donors.

Methods-bFGF was isolated by heparin affinity chromatography and characterised by western blotting and endothelial cell bioassay. bFGF was measured by immunoassay and its distribution defined by immunohistochemistry and in situ hybridisation. Binding of bFGF by heparan sulphate proteoglycans was investigated by sodium chloride and heparin extraction.

Results-Bioactive bFGF (19 kDa) was detected in normal mucosa but bFGF mRNA was not found. bFGF expression was up regulated in granulation tissue endothelial cells, mononuclear cells, and epithelial cells at the ulcer rim. Gastric ulcer patients had constitutively low bFGF concentrations in intact antral mucosa which were not explained by changes in binding to heparan sulphate proteoglycans.

Conclusions-bFGF expression is up regulated in human gastric ulcers. Low intact mucosal bFGF content is associated with gastric ulceration.

(Gut 1998;43:525-536)
\end{abstract}

Keywords: basic fibroblast growth factor; gastric mucosa; heparan sulphate proteoglycan; peptic ulceration

Gastroenterology

M A Hull

J L Brough

C J Hawkey

Division of Histopathology, University Hospital, Nottingham, UK

D G Powe

G I Carter

D Jenkins

Correspondence to: Dr M A Hull, Division of Medicine, St James's University Hospital, Leeds LS9 7TF, UK. motes healing of gastric ulcers, there is little evidence for a role for endogenous mucosal $\mathrm{bFGF}$ in gastric ulcer repair. Increased expression of bFGF has been noted in granulation tissue of gastric ${ }^{1}$ and duodenal ulcers ${ }^{4}$ in rats and a neutralising anti-bFGF antibody delayed healing of gastric ulcers in the same rat model. ${ }^{1}$ bFGF has been isolated from human gastric mucosa, obtained after gastric carcinoma resection, ${ }^{4}$ and two groups have reported the immunohistochemical localisation of bFGF in normal gastric mucosa with conflicting results ${ }^{5}$; there are however no data on bFGF expression in gastric ulcer patients. bFGF is believed to be bound by heparan sulphate proteoglycans (HSPGs) which may modulate bFGF activity at the cell surface, ${ }^{7}$ protect bFGF from inactivation by acid and proteolysis, ${ }^{8}$ and act as a "storage site" of preformed bFGF for release following tissue injury. ${ }^{9}$

In this study, we investigated bFGF expression and binding by mucosal HSPGs in intact and ulcerated human gastric mucosa. We tested the hypothesis that decreased mucosal bFGF content or altered binding to HSPGs is associated with ulceration and that bFGF expression is up regulated in human gastric ulcers.

\section{Materials and methods}

ETHICAL APPROVAL

Written permission to collect endoscopic gastric biopsy specimens from outpatients undergoing upper gastrointestinal endoscopy, gastric ulcer resection specimens from patients undergoing laparotomy for haemorrhage or perforation, and whole stomachs from organ donors was obtained from patients and relatives. Studies were approved by the University Hospital Ethics Committee.

ISOLATION AND CHARACTERISATION OF GASTRIC MUCOSAL bFGF

Heparin affinity chromatography

Gastric mucosa was obtained from organ donor stomachs by dissection and weighed. Mucosa was homogenised on ice for two minutes in $4 \mathrm{ml}$ extraction buffer $(10 \mathrm{mmol} / 1$ Tris-Cl (pH 7.4), $2 \mathrm{~mol} / 1 \mathrm{NaCl}, 1 \mathrm{mmol} / \mathrm{l}$ EDTA, $1 \mathrm{mmol} / 1$ phenylmethylsulphonyl fluoride, $1 \mu \mathrm{g} / \mathrm{ml}$ aprotinin, and $1 \mu \mathrm{g} / \mathrm{ml}$ pepstatin A (all Sigma, Poole, UK)) per gram of mucosa. The homogenate was sonicated for 30 seconds $\times 5$ and stirred overnight at $4^{\circ} \mathrm{C}$. The homogenate was centrifuged $(2000 \mathrm{~g}, 15$ minutes at $4^{\circ} \mathrm{C}$ ) to remove tissue debris and then ultracentrifuged $\left(15000 \mathrm{~g}, 30\right.$ minutes at $\left.4^{\circ} \mathrm{C}\right)$. Decanted supernatant was diluted $\times 4$ with 10 $\mathrm{mmol} / \mathrm{l}$ Tris-Cl ( $\mathrm{pH} 7.4)$.

A $5 \mathrm{ml}$ heparin-sepharose column (Pharmacia Biotech Ltd, St Albans, UK), equilibrated with $25 \mathrm{ml} 10 \mathrm{mmol} / 1$ Tris-Cl (pH 7.4) was 
connected to a low pressure chromatography system (Econo system, Bio-Rad Laboratories Ltd, Hemel Hempstead, UK) and the supernatant added. The column was washed with 10 $\mathrm{mmol} / 1$ Tris- $\mathrm{Cl}$ ( $\mathrm{pH} 7.4$ ), $0.6 \mathrm{~mol} / 1 \mathrm{NaCl}$ until the eluate read background absorbance at 280 $\mathrm{nm}$. Heparin bound proteins were eluted using an $80 \mathrm{ml}$ gradient of $0-3 \mathrm{~mol} / 1 \mathrm{NaCl}$ in 10 $\mathrm{mmol} / 1$ Tris- $\mathrm{Cl}(\mathrm{pH}$ 7.4). Forty $2 \mathrm{ml}$ fractions were collected and equilibrated with $10 \mathrm{mmol} / 1$ Tris-Cl (pH 7.4), $0.15 \mathrm{~mol} / 1 \mathrm{NaCl}$ using $9 \mathrm{ml}$ Sephadex G-25 columns (Pharmacia) before assay for $\mathrm{bFGF}$.

\section{bFGF enzyme linked immunosorbent assay} (ELISA)

The bFGF ELISA was similar to that previously described by Watanabe et al..$^{10}$ Briefly, samples or standards $(100 \mu \mathrm{l})$ were added to an equal volume of $100 \mu \mathrm{g} / \mathrm{ml}$ porcine heparin (Sigma) in blocking solution (25\% Block Ace (Wako Chemicals, Osaka, Japan) in phosphate buffered saline (PBS)) and $100 \mu \mathrm{l}$ aliquots were added in duplicate to wells coated with two murine monoclonal antirecombinant human bFGF antibodies (Mab52 and Mab98; Wako) at $5 \mu \mathrm{g} / \mathrm{ml}$. After overnight incubation at $4^{\circ} \mathrm{C}$ and washing with deionised water, the Fab' fragment of a third murine monoclonal antibFGF antibody (Mab3H3; Wako) conjugated to horseradish peroxidase (HRP) in blocking solution was added to wells at $3 \mu \mathrm{g} / \mathrm{ml}$ and incubated for two to four hours at room temperature. Following further washes with deionised water and PBS, o-phenylenediamine dihydrochloride $(2 \mathrm{mg} / \mathrm{ml}$, Sigma) and $0.03 \%$ $\mathrm{H}_{2} \mathrm{O}_{2}$ were added to each well and incubated in the dark at room temperature for 60 minutes. The reaction was terminated by addition of 2 $\mathrm{mol} / 1 \mathrm{H}_{2} \mathrm{SO}_{4}$. Absorbance at $492 \mathrm{~nm}$ was measured using a Dynatech MR5000 microplate reader.

There was no cross reactivity with FGF1, 4, 5 , 6, or keratinocyte growth factor (FGF7) using this ELISA (own data, not shown; see also Watanabe et $\left.a l^{10}\right)$.

Sodium dodecyl sulphate-polyacrylamide gel electrophoresis (SDS-PAGE)

Aliquots $(500 \mu \mathrm{l})$ from heparin affinity chromatography fractions were pooled, freeze dried, and reconstituted in $100 \mu \mathrm{l}$ double distilled (dd) $\mathrm{H}_{2} \mathrm{O}$. An equal volume of $2 \times$ electrophoresis sample buffer $(0.125 \mathrm{~mol} / 1$ Tris-Cl $(\mathrm{pH}$ 6.8), $4 \%$ SDS, $10 \%$ mercaptoethanol, $20 \%$ sucrose, $0.004 \%$ bromophenol blue; all Sigma) was added to $7.5 \mu \mathrm{l}$ of pooled eluate and boiled for five minutes before cooling on ice. Samples were electrophoresed on $12.5 \% \quad 29 / 1$ acrylamide/bis-acrylamide minigels along with molecular weight markers (SDS-PAGE Broad Range Molecular Weight Standards, Bio-Rad) and $7.5 \mu \mathrm{l} 250 \mu \mathrm{g} / \mathrm{ml}$ carrier free recombinant bFGF corresponding to amino acid residues 9-155 of human bFGF (R\&D Systems Europe, Abingdon, UK). Minigels were fixed in $20 \%$ methanol $/ 7.5 \%$ acetic acid and stained with $0.1 \%$ Coomassie brilliant blue R-250 (Bio-Rad) as well as a silver stain (Silver Stain Plus, Bio-Rad).
Western blot analysis

Following SDS-PAGE, proteins were blotted onto $0.2 \mu \mathrm{m}$ nitrocellulose membrane (BioRad) using a semidry transfer cell (Bio-Rad). The membrane was blocked with $3 \%$ gelatin in Tris-buffered saline (TBS) for 60 minutes and washed with $0.05 \%$ Tween-20 (Sigma) in TBS before incubation with $1 \mu \mathrm{g} / \mathrm{ml}$ goat polyclonal antihuman bFGF antibody (R\&D Systems) at $4^{\circ} \mathrm{C}$ overnight. After further washes with $0.05 \%$ Tween-20, the membrane was incubated with a $1 / 2000$ dilution of rabbit antigoat IgG-HRP (Sigma) at room temperature for 60 minutes before addition of substrate (4-chloro1-napthol $/ \mathrm{H}_{2} \mathrm{O}_{2}$; Bio-Rad).

\section{Bioassay of gastric mucosal bFGF}

Heparin affinity chromatography fractions were pooled, freeze dried, and resuspended in $500 \mu \mathrm{ldd} \mathrm{H}_{2} \mathrm{O}$. This solution was exchanged for $10 \mathrm{mmol} / 1$ Tris-Cl (pH 7.4), $0.15 \mathrm{~mol} / 1$ $\mathrm{NaCl}$ using gel filtration (Bio-Spin 6, Bio-Rad) and sterilised using a $0.2 \mu \mathrm{m}$ filter (Sartorius AG, Gottingen, Germany).

A $95 \mu \mathrm{l}$ aliquot of this solution or $10 \mathrm{mmol} / \mathrm{l}$ Tris-Cl ( $\mathrm{pH} 7.4$ ), $0.15 \mathrm{~mol} / 1 \mathrm{NaCl}$ were preincubated with $5 \mu \mathrm{l}$ of $1 \mathrm{mg} / \mathrm{ml} \mathrm{Mab3H3}$ or $5 \mu \mathrm{l}$ PBS for 60 minutes at room temperature. Mab3H3 has previously been shown to neutralise the effects of bFGF in vivo and in vitro ${ }^{11}$ and we have shown that the concentration used here $(50 \mu \mathrm{g} / \mathrm{ml})$ inhibits the proliferative activity of $10 \mathrm{ng} / \mathrm{ml}$ recombinant human bFGF on human umbilical vein endothelial cells (HUVECs; data not shown). The mitogenic activity of these samples on human gastric endothelial (HuGE) cells was measured using a colorimetric proliferation assay as previously described. ${ }^{12}$

IMMUNOHISTOCHEMISTRY FOR bFGF

Formalin fixed, paraffin wax embedded sections ( $4 \mu \mathrm{m}$ thick) of gastric mucosa and Dupytren's contracture (used as a positive control $)^{13}$ were dewaxed and rehydrated. Endogenous peroxidase activity was blocked with 4 parts methanol/1 part $3 \% \mathrm{H}_{2} \mathrm{O}_{2}$ for 20 minutes. After washing in PBS, sections were blocked with $10 \%$ rabbit serum in PBS for 60 minutes at room temperature. Sections were incubated with Mab52 (6 $\mu \mathrm{g} / \mathrm{ml})$ diluted in $10 \%$ rabbit serum at $4{ }^{\circ} \mathrm{C}$ overnight. Mab52 did not cross react with FGF1, 4, 5, 6, or 7 up to 1 $\mathrm{ng} / \mathrm{ml}$ when tested by direct ELISA (data not shown).

Following PBS washes $(3 \times$ five minutes), sections were incubated with a $1 / 400$ dilution of biotinylated polyclonal rabbit antimouse immunoglobulin antibody (Dako Ltd, High Wycombe, UK) and visualised using streptavidin-biotin-HRP (Dako) and 3,3'diaminobenzidine $/ \mathrm{H}_{2} \mathrm{O}_{2}$ (both $0.7 \mathrm{mg} / \mathrm{ml}$; Sigma). Controls comprised omission of the primary antibody, substitution of the primary antibody with a non-specific mouse $\operatorname{IgG}_{2 \mathrm{~b}}$ monoclonal antibody (anti-Aspergillus niger glucose oxidase; Dako) and preabsorption of the primary antibody with ninefold molar excess of bFGF for two hours at $4^{\circ} \mathrm{C}$ before use. 
Mucosal bFGF content was assessed using a semiquantitative scoring system by an experienced histopathologist (DJ) blind to the origin of the sections and the corresponding bFGF concentration. Epithelial cell, lamina propria, smooth muscle, and muscularis mucosae staining was scored on a scale from $0-3(0$, absent staining; 1 , weak staining, just visible; 2 , moderate staining, easily seen; 3, strong staining). A total bFGF score was obtained by addition of individual components. Adjacent sections stained with haematoxylin and eosin $(\mathrm{H} \& \mathrm{E})$ were assessed independently for acute and chronic inflammatory infiltration, atrophy, and reactive gastritis (foveolar hyperplasia, presence of dilated, superficial capillaries, and lamina propria smooth muscle infiltration) using a scale of $0-3$ by the same histopathologist.

IN SITU HYBRIDISATION OF bFGF mRNA

Preparation of bFGF $c D N A$ probe

Plasmid pTB669 was a kind gift from Dr Toguchi (Pharmaceutical Research Division, Takeda). Plasmid pTB669 contains a 450 bp cDNA insert corresponding to the coding sequence for amino acid residues 4-146 of human bFGF. $^{14}$

bFGF cDNA was excised using EcoRI and BgIII (Northumbria Biologicals Ltd, Cramlington, UK). bFGF cDNA and pBluescript II SK DNA (SK II, Stratagene, La Jolla, California, USA) were labelled with ${ }^{35}$ S-dCTP (1000$1500 \mathrm{Ci} / \mathrm{mmol}$, Amersham, Little Chalfont, UK) or ${ }^{32} \mathrm{P}-\mathrm{dCTP}(3000 \mathrm{Ci} / \mathrm{mmol}$, Amersham) for in situ hybridisation or northern blot analysis respectively using a random priming technique (Nonaprimer II, Appligene, Birtley, UK). Labelled probes were purified using silica gel chromatography (QIAGEN Ltd, Dorking, UK).

\section{Northern blot analysis}

Gastric mucosa from the antrum of two organ donor stomachs was snap frozen at $-70^{\circ} \mathrm{C}$ immediately after excision. Total RNA was extracted by a guanidium isothiocyanatephenol-chloroform extraction technique (Trizol, GIBCO BRL, Paisley, Scotland, UK) based on the method of Chomczynski and Sacchi. ${ }^{15}$ Poly A ${ }^{+}$RNA was obtained using poly dT affinity chromatography (QIAGEN). Poly $\mathrm{A}^{+}$RNA (1 $\left.\mu \mathrm{g}\right)$ was electrophoresed and blotted onto Hybond-N nylon membrane (Amersham) by capillary transfer overnight and then crosslinked to the membrane using ultraviolet light. The membrane was hybridised with $10^{6} \mathrm{cpm} / \mathrm{ml}{ }^{32} \mathrm{P}$-dCTP labelled bFGF cDNA probe in $5 \times$ SSPE, $5 \times$ Denhardt's solution (Sigma), $0.5 \% \mathrm{SDS}$ at $65^{\circ} \mathrm{C}$ overnight. The final stringency wash was $2 \times 20$ minutes in $0.1 \times \mathrm{SSPE}, 0.1 \% \mathrm{SDS}$ at $50^{\circ} \mathrm{C}$. Autoradiography was for 96 hours at $-70^{\circ} \mathrm{C}$ using Kodak $\mathrm{X}-\mathrm{Omat}$ AR film (Sigma) and two intensifying screens.

Confirmation that the bFGF cDNA probe hybridised with known bFGF mRNA species was obtained by northern blot analysis of $1 \mu \mathrm{g}$ poly $\mathrm{A}^{+}$from human omental microvascular endothelial (HOME) cells and HUVECs.
In situ hybridisation

The method used was similar to that of Sandberg and Vuorio. ${ }^{16}$ Sections $(4 \mu \mathrm{m})$ of formalin fixed, paraffin wax processed gastric mucosa and Dupytren's contracture were dewaxed and rehydrated. Sections were incubated in $0.2 \mathrm{~N}$ $\mathrm{HCl}$ for 20 minutes and then washed in $2 \times$ SSC (standard saline citrate; $1 \times$ SSC $=0.15$ $\mathrm{mol} / 1 \mathrm{NaCl}, 0.015 \mathrm{~mol} / 1$ trisodium citrate) at $70^{\circ} \mathrm{C}$ for 10 minutes before digestion with 10 $\mu \mathrm{g} / \mathrm{ml}$ proteinase $\mathrm{K}$ (Sigma) for 15 minutes at $37^{\circ} \mathrm{C}$. Sections were then acetylated with $0.25 \%$ acetic anhydride in $0.1 \mathrm{~mol} / 1$ triethanolamine $(\mathrm{pH} \mathrm{8)}$ for 10 minutes. Sections were hybridised overnight at $42^{\circ} \mathrm{C}$ with $10^{5}-10^{6}$ $\mathrm{cpm} / \mathrm{section}$ of ${ }^{35} \mathrm{~S}$ labelled bFGF cDNA probe in $50 \%$ formamide, $10 \mathrm{mmol} / 1$ dithiothreitol (DTT), $1 \times$ Denhardt's solution, $0.6 \mathrm{~mol} / 1$ $\mathrm{NaCl}, 10 \mathrm{mmol} / 1$ Tris, $2 \mathrm{mmol} / 1$ EDTA, 10\% dextran sulphate, and 3\% salmon sperm DNA (Sigma). Negative control sections were incubated with ${ }^{35} \mathrm{~S}$ labelled SK II DNA of similar activity. Sections were given stringency washes in $0.5 \times \mathrm{SSC}, 1 \mathrm{mmol} / 1 \mathrm{EDTA}, 10 \mathrm{mmol} / 1 \mathrm{DTT}$ at $42^{\circ} \mathrm{C}$ for 10 minutes followed by $2 \times 10$ minute washes with $0.5 \times \mathrm{SSC}, 1 \mathrm{mmol} / 1 \mathrm{EDTA}$ at $42^{\circ} \mathrm{C}$. Sections were then washed with $50 \%$ formamide, $0.15 \mathrm{~mol} / 1 \mathrm{NaCl}, 0.5 \mathrm{mmol} / 1$ EDTA, $5 \mathrm{mmol} / 1$ Tris-Cl (pH 7.4) at room temperature for 10 minutes. Four five minute washes with $0.5 \times \mathrm{SSC}$ at $55^{\circ} \mathrm{C}$ were followed by a wash with $0.5 \times$ SSC at room temperature. The probe was localised using Hypercoat LM-1 emulsion (Amersham) autoradiography with exposure for up to 28 days at $4^{\circ} \mathrm{C}$. Sections were counterstained with haematoxylin.

MEASUREMENT OF GASTRIC MUCOSAL bFGF CONCENTRATIONS

Upper gastrointestinal endoscopy using an Olympus PQ-20 or XP-10 endoscope was performed on outpatients who attended routine endoscopy lists or an NSAID screening programme. A gastric ulcer was defined as having a diameter of greater than $3 \mathrm{~mm}$ and perceptible depth. Four biopsy specimens were taken from the ulcer rim if present and four from macroscopically normal antral mucosa at least $2 \mathrm{~cm}$ distant from the ulcer using forceps with a $5 \mathrm{~mm}$ bite. Ulcer rim biopsy specimens were taken at $45^{\circ}$ from the mucosal surface in an attempt to include ulcer base and intact mucosa in equal proportions. Two further biopsy specimens from intact antral mucosa were placed in formalin, stained with $\mathrm{H} \& \mathrm{E}$, and examined for acute and chronic inflammatory infiltration, atrophy, and reactive gastritis as described. A final antral biopsy specimen was taken for a rapid urease test. Age, sex, smoking status, past history of gastric ulceration, ulcer healing drug use, and NSAID use were noted at the same time. An NSAID user was defined as one taking NSAIDs regularly more than three days per week.

Biopsy specimens were immediately placed in $1 \mathrm{ml} 10 \mathrm{mmol} / 1$ Tris-Cl (pH 7.4), $0.15 \mathrm{~mol} / 1$ $\mathrm{NaCl}$, vortexed briefly, and pulse centrifuged. The biopsy specimens were removed from the wash solution and dried briefly on filter paper 


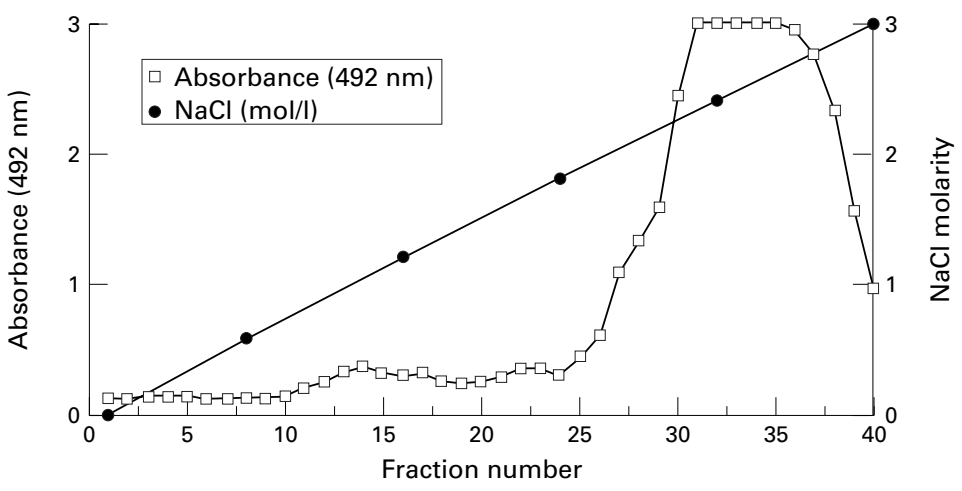

Figure 1 Elution of bFGF from human gastric mucosa using heparin affinity chromatography and a $0-3 \mathrm{~mol} / \mathrm{l} \mathrm{NaCl}$ gradient. bFGF content of each fraction was assessed using a bFGF ELISA. A peak of bFGF was detected in fractions 30-40 corresponding to elution by $1.8-2.8 \mathrm{~mol} / \mathrm{l} \mathrm{NaCl}$.

before weighing. Specimens were placed in 600 $\mu \mathrm{l}$ fresh $10 \mathrm{mmol} / 1$ Tris-Cl (pH 7.4), $0.15 \mathrm{~mol} / 1$ $\mathrm{NaCl}$ and homogenised for 60 seconds using an Ultra-Turrax T25 homogeniser. Homogenates were immediately centrifuged at $15000 \mathrm{~g}$ for 60 seconds. The supernatant was collected and added to an equal volume of PBS containing $100 \mu \mathrm{g} / \mathrm{ml}$ heparin and 25\% Block Ace. Aliquots $(100 \mu \mathrm{l})$ of this solution were added to a bFGF ELISA plate. Results are expressed as pg bFGF per mg wet weight of biopsy specimen. Intra-assay coefficient of variation of the ELISA was $6.1 \%$ (mean bFGF concentration $94.0 \mathrm{pg} /$ well; $\mathrm{n}=8$ ). Interassay coefficient of variation was $22.0 \%$ (mean bFGF concentration $19.0 \mathrm{pg} /$ well; $\mathrm{n}=4$ ). Recovery of added recombinant bFGF (2 pg/well) to homogenate supernatant was $130 \%$.

bFGF EXTRACTION FROM GASTRIC MUCOSA BY $\mathrm{NaCl}$ AND HEPARIN

Two sets of four biopsy specimens were obtained from other patients undergoing upper gastrointestinal endoscopy and were washed, weighed, and homogenised in $600 \mu 110 \mathrm{mmol} / 1$ Tris-Cl ( $\mathrm{pH} 7.4), 0.15 \mathrm{~mol} / 1 \mathrm{NaCl}$ as described above except that homogenates were incubated for 10 minutes on ice before centrifugation.

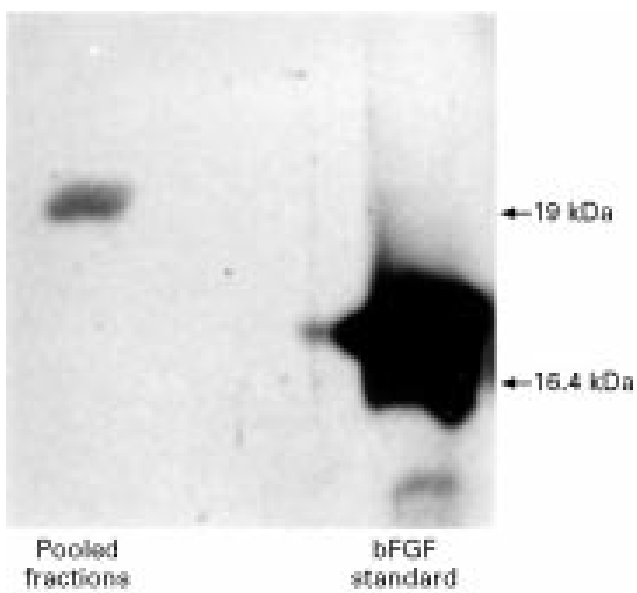

Figure 2 Western blot analysis of gastr ic mucosal bFGF. Fractions 30-40 from heparin affinity chromatography were pooled, freeze dried, and reconstituted in $100 \mu \mathrm{l} \mathrm{H} \mathrm{H}_{2} \mathrm{O}$ Gastric mucosa contained a $19 \mathrm{kDa}$ isoform of bFGF compared with $16.4 \mathrm{kDa} N$-terminal truncated recombinant $b F G F$ :
Homogenates were centrifuged at $15000 \mathrm{~g}$ for 60 seconds and supernatants were collected. One of the pair of gastric mucosal pellets was resuspended in $600 \mu \mathrm{l}$ ice cold $10 \mathrm{mmol} / \mathrm{l}$ Tris-Cl ( $\mathrm{pH} 7.4$ ), $0.5 \mathrm{~mol} / 1 \mathrm{NaCl}$, vortexed for 60 seconds, and left on ice for 10 minutes. The sample was centrifuged and the supernatant collected. This process was repeated with separate $600 \mu \mathrm{l}$ aliquots of $10 \mathrm{mmol} / \mathrm{l}$ Tris- $\mathrm{Cl}(\mathrm{pH}$ 7.4) with added $1.0 \mathrm{~mol} / 1,1.5 \mathrm{~mol} / \mathrm{l}$, and 2.0 $\mathrm{mol} / \mathrm{l} \mathrm{NaCl}$. Remaining bFGF in the pellet was extracted using $600 \mu \mathrm{l}$ of $100 \mu \mathrm{g} / \mathrm{ml}$ heparin (Sigma) in $10 \mathrm{mmol} / 1$ Tris-Cl (pH 7.4), 0.15 $\mathrm{mol} / \mathrm{l} \mathrm{NaCl}$. Finally, extraction of residual bFGF was performed using $10 \mathrm{mmol} / 1$ Tris-Cl (pH 7.4), $3.0 \mathrm{~mol} / 1 \mathrm{NaCl}$.

All supernatants were buffer exchanged with $10 \mathrm{mmol} / 1$ Tris-Cl (pH 7.4), $0.15 \mathrm{~mol} / 1 \mathrm{NaCl}$ using Biospin 6 columns (Bio-Rad). Samples were stored at $-30^{\circ} \mathrm{C}$ until assay for bFGF by ELISA.

At the same time, the other mucosal pellet (control) was handled in a similar fashion except that increasing $\mathrm{NaCl}$ concentrations were replaced by repeated $600 \mu \mathrm{l}$ aliquots of 10 $\mathrm{mmol} / 1$ Tris-Cl ( $\mathrm{pH} 7.4$ ), $0.15 \mathrm{~mol} / 1 \mathrm{NaCl}$. After this, incubation with $100 \mu \mathrm{g} / \mathrm{ml}$ heparin solution followed by $10 \mathrm{mmol} / \mathrm{l}$ Tris- $\mathrm{Cl}(\mathrm{pH}$ 7.4), $3.0 \mathrm{~mol} / 1 \mathrm{NaCl}$ was carried out as above. Buffer exchange was also performed on control supernatants. Salt and control extracts were assayed in duplicate by bFGF ELISA.

\section{STATISTICAL ANALYSIS}

Gastric mucosal homogenate bFGF concentrations did not have a normal distribution and so were logarithmically transformed before statistical analysis by Student's $t$ test for paired and unpaired data. Data are expressed as the geometric mean and 95\% confidence interval (CI). bFGF histology and gastritis scores were

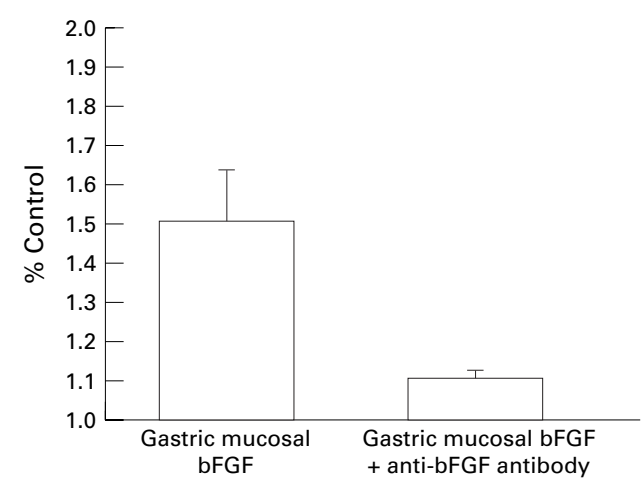

Figure 3 Mitogenic activity of gastric mucosal bFGF. $H u G E$ cell number was assayed using a formazan colorimetric assay (Promega, Madison, Wisconsin). We have previously shown a good correlation $\left(r^{2}=0.99\right)$ between absorbance at $492 \mathrm{~nm}$ and HuGE cell number using this assay. ${ }^{12}$ Briefly, $10^{3} \mathrm{HuGE}$ cells were added to individual 1\% gelatin coated wells of a 96 well plate and incubated for 48 hours in $5 \% \mathrm{CO}_{2}$ at $37^{\circ} \mathrm{C}$ in the absence of endothelial cell growth supplement. Gastric mucosal bFGF or control buffer with or without Mab3H3 (working concentration $50 \mu \mathrm{g} / \mathrm{ml}$ ) was added to $\mathrm{HuGE}$ cell monolayers and incubated for a further 24 hours before assay. Data are expressed as the mean (SEM) multiple of the absorbance at $492 \mathrm{~nm}$ of the negative control $(n=4$ wells). Gastric mucosal bFGF promoted proliferation of $H u G E$ cells which was almost completely inhibited by Mab3H3. Cell number was not affected by the presence of Mab3H3 per se (data not shown). 

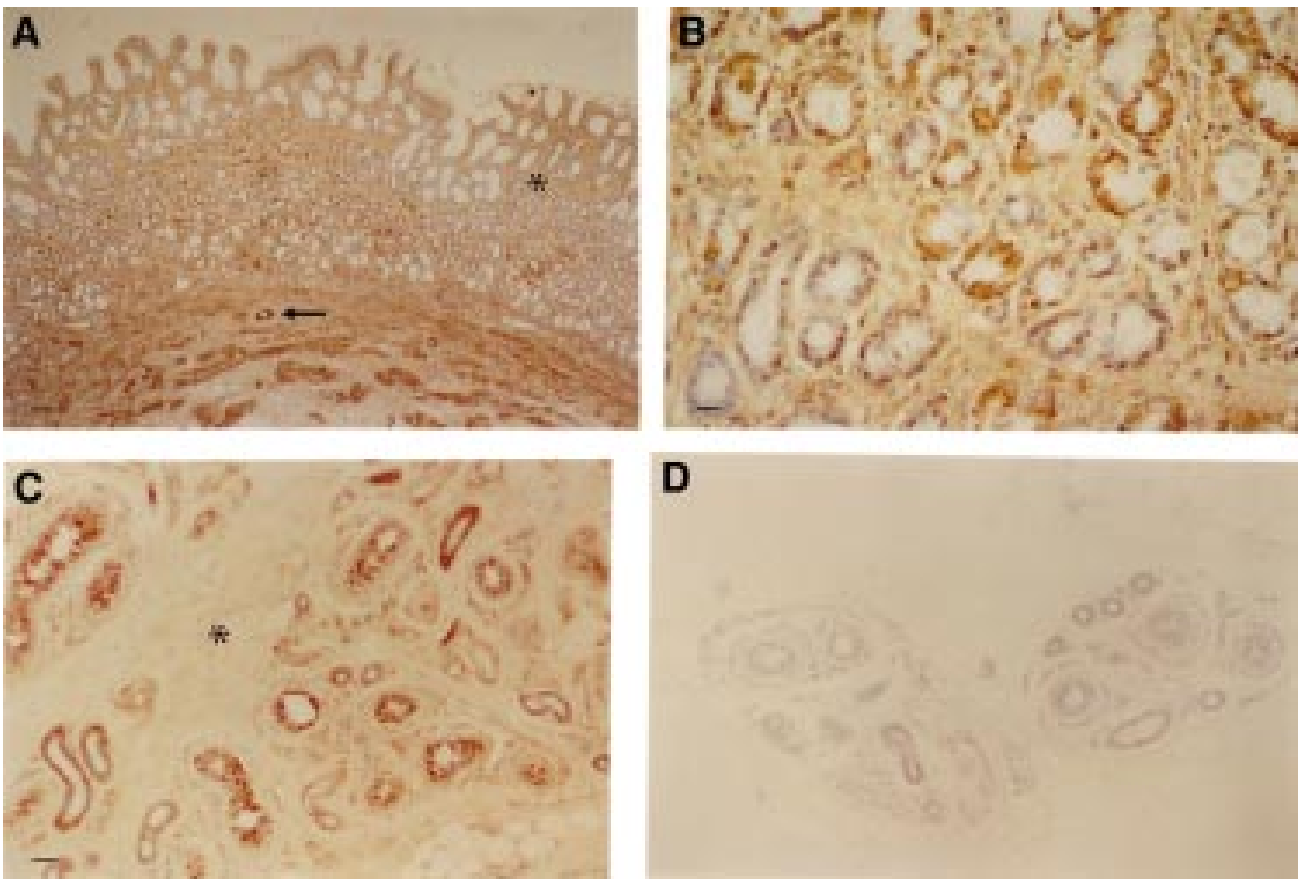

Figure 4 Immunohistochemistry for bFGF in normal tissue. (A) Normal antral mucosa. Localisation of bFGF to surface and glandular epithelium, lamina propria extracellular matrix (ECM) (asterisk), muscularis, and blood vessels (arrow). Bar $=80 \mu m$. (B) Normal antral mucosa. Patchy distribution of bFGF in glandular epithelium. Bar $=20 \mu m$. (C)

Dupytren's contracture. Staining of sweat glands, blood vessels, and ECM (asterisk). Bar=40 $\mu m$. (D) Dupytren's contracture. Preabsorption of Mab52 by recombinant human bFGF ( $\times 9$ molar excess). No staining. Scale as for (C).

compared using the Mann-Whitney $U$ test. Multivariate analysis of variance was used to determine whether Helicobacter pylori status, NSAID use, or type and degree of gastritis accounted for differences in bFGF concentrations and bFGF histology scores between patient groups.

bFGF concentrations extracted from gastric mucosa using $\mathrm{NaCl}$ and heparin are expressed as the arithmetic mean and standard error of the mean (SEM) and differences were analysed using Student's $t$ test.

\section{Results}

bFGF PROTEIN IN NORMAL HUMAN GASTRIC MUCOSA

Isolation and characterisation of gastric mucosal $b F G F$

Basic FGF eluted from heparin-sepharose between $1.8 \mathrm{~mol} / 1$ and $2.8 \mathrm{~mol} / 1 \mathrm{NaCl}$ (fig 1 ). The elution profile was similar from three organ donor stomachs. Western blot analysis of pooled fractions 30-40 revealed a single 19 $\mathrm{kDa} b F G F$ isoform (fig 2). Silver staining of the pooled fractions showed no contaminating protein. Gastric mucosal bFGF, isolated in this manner, stimulated proliferation of $\mathrm{HuGE}$ cells (fig 3). Preincubation with Mab3H3 inhibited the proliferative response to gastric mucosal bFGF by more than $80 \%$ (fig 3 ).

\section{Immunohistochemistry}

Sections of normal gastric antral and body mucosa from organ donors, who were not taking NSAIDs, were used. There was no histological evidence of stress ulceration or $H$ pylori infection in these cases.

In antral mucosa, staining of bFGF was present in glandular epithelial cells and surface epithelium (fig 4A). In gastric glands, the distribution of bFGF was patchy. Staining appeared to be diffusely cytoplasmic (fig 4B) although a few cells had some punctate nuclear staining. Basic FGF immunoreactivity was also detected in extracellular matrix surrounding lamina propria cells and glands (fig 4A). There was also staining of muscularis mucosae and endothelium of arterioles (fig 4A). Endothelial cells of microvessels in the lamina propria contained less immunoreactive bFGF than those of larger vessels.

In body mucosa, there was a similar pattern of staining but glandular epithelium was less intensely stained than antral epithelium.

There was specific staining of sweat glands, blood vessels, and occasional myofibroblasts in Dupytren's contracture (fig 4C) in agreement with published data on the distribution of bFGF in this tissue. ${ }^{13}{ }^{17}$ Control sections of Dupytren's contracture and gastric mucosa revealed no staining (fig $4 \mathrm{D}$ ).

bFGF MRNA IN NORMAL HUMAN GASTRIC MUCOSA bFGF mRNA was not detected in normal human gastric mucosa by northern blot analysis although the bFGF probe detected three bFGF mRNAs in HOME cells $(6.6,2.0$, and $1.0 \mathrm{~kb}$ ) and one in HUVECs (6.6 kb; data not shown) confirming previous data. ${ }^{18}$ Similarly, there was no hybridisation of the bFGF probe

Table 1 Gastric ulcer patients and non-ulcer controls from whom endoscopic biopsy samples were taken

\begin{tabular}{lll}
\hline & Ulcer & Non-ulcer \\
\hline No of subjects & 17 & 52 \\
Mean (SEM) age (y) & $56(4)$ & $57(2)$ \\
Sex (M:F) & $9: 8$ & $22: 30$ \\
Smoker (\%) & $5(29)$ & $12(23)$ \\
H pylori infection (\%) & $8(47)$ & $23(44)$ \\
NSAID use (\%) & $12(59)$ & $33(63)$ \\
\hline
\end{tabular}


Table 2 Multivariate analysis of variance of factors which could account for the low intact gastric mucosal bFGF concentrations measured by ELISA

\begin{tabular}{lll}
\hline Factor & F ratio & p Value \\
\hline NSAID use & 0.38 & 0.54 \\
Atrophic gastritis & 0.77 & 0.52 \\
H pylori status & 1.27 & 0.28 \\
Reactive gastritis & 1.52 & 0.20 \\
Inflammatory gastritis & 1.62 & 0.17 \\
Presence of gastric ulcer & 18.60 & $<0.0001$ \\
\hline
\end{tabular}

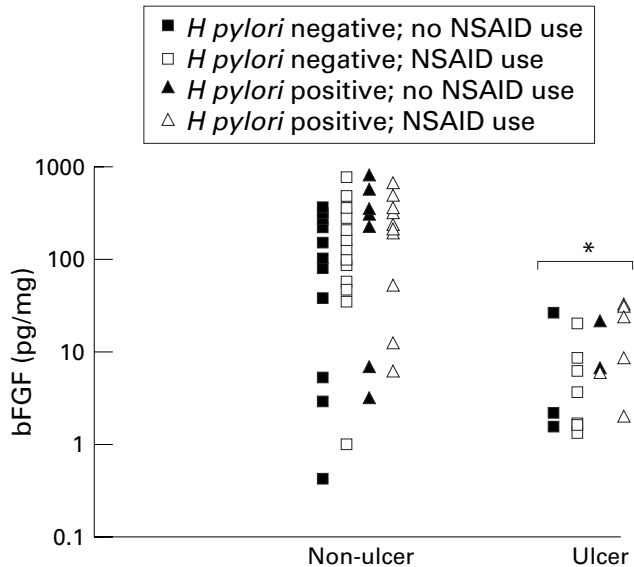

Figure 5 Intact mucosal bFGF concentrations in gastric ulcer patients and matched non-ulcer controls. ${ }^{\star} p<0.001$.

with sections of normal antral and body mucosa although specific signal was detected over occasional fibroblastoid cells and arteriolar smooth muscle of Dupytren's contracture as described previously. ${ }^{13}{ }^{17}$ No specific hybridisation was shown with the control (SK II) probe.

LOW bFGF CONCENTRATIONS IN INTACT GASTRIC MUCOSA OF ULCER PATIENTS

Next, we investigated whether differences in bFGF expression in intact mucosa were associated with the presence of gastric ulceration. Intact mucosal bFGF concentrations from 17 gastric ulcer patients were compared with corresponding values from 52 age and sex matched non-ulcer control patients. Table 1 shows that these two groups were well matched for NSAID use, $H$ pylori, and smoking status. bFGF concentrations in intact antral mucosa of ulcer patients (mean $10.4 \mathrm{pg} / \mathrm{mg}$; $95 \%$ confidence interval (CI) 5.3-15.5) were notably lower than in intact mucosa of non-ulcer controls (234.0 pg/mg; CI 174.0-294.0) ( $<<$
0.001; fig 5). Lower intact mucosal bFGF concentrations in gastric ulcer patients were not explained by differences in NSAID use, $H$ pylori status, or type and degree of gastritis between ulcer patients and non-ulcer controls when assessed by multivariate analysis of variance (table 2).

Repeat antral biopsy specimens were obtained from the antrum of eight gastric ulcer patients at eight weeks, at which time complete ulcer healing had occurred in all cases. Acid suppressing drugs were still being used at the time of endoscopy (three patients received standard healing doses of an $\mathrm{H}_{2}$ receptor antagonist and five patients were enrolled into a blinded study of omeprazole $20 \mathrm{mg}$ or $40 \mathrm{mg}$ daily or misoprostol $200 \mu \mathrm{g}$ four times daily for healing of NSAID associated gastric ulcers). Intact mucosal bFGF concentrations rose significantly following ulcer healing with acid suppressing drugs (mean 8.9 (CI 1.8-16.0) $\mathrm{pg} / \mathrm{mg}$ prehealing versus 41.5 (CI 12.3-70.7) $\mathrm{pg} / \mathrm{mg}$ posthealing; $\mathrm{p}=0.02$ ) but concentrations did not reach those seen in non-ulcer control patients (fig 5).

Histological assessment of bFGF content in intact antral mucosa was carried out in 10 gastric ulcer patients and eight non-ulcer controls which were matched for age, sex, $H$ pylori status, and NSAID use. The distribution of bFGF was similar to that described in normal gastric mucosa. In cases in which a chronic inflammatory infiltrate was present, an increase in lamina propria mononuclear cells positive for bFGF was seen (fig 6A). Superficial lamina propria muscle fibres in gastric mucosa showing other features of reactive gastritis stained positively for bFGF (fig 6B). There was a strong positive correlation between the degree of reactive gastritis and the $\mathrm{bFGF}$ histology score in individual patients $(r=0.75, \mathrm{p}<0.001$; Spearman rank correlation). Otherwise, there was no effect of the type and degree of gastritis on bFGF immunostaining. Antral mucosa from gastric ulcer patients had a significantly higher bFGF histology score (and degree of reactive gastritis) than mucosa from non-ulcer patients despite having notably lower bFGF concentrations measured by ELISA (table 3 ).

BINDING OF bFGF TO GASTRIC MUCOSAL HSPGs We then investigated whether alterations in strength of binding of bFGF to gastric mucosal HSPGs could explain low bFGF concentra-

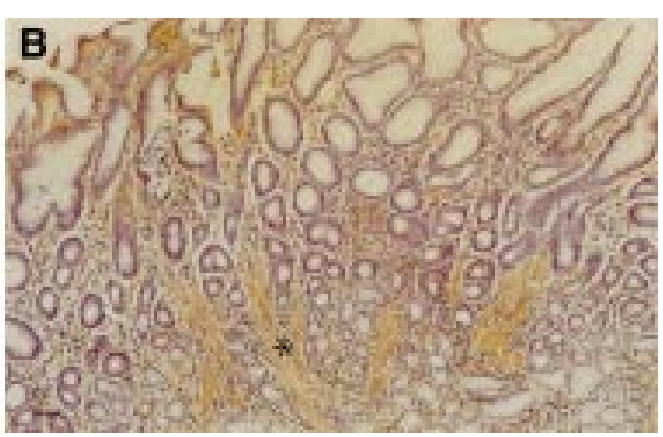

Figure 6 Immunohistochemistry for bFGF in antral gastric mucosa. (A) H pylori associated gastritis. Strongly stained mononuclear cells present in a chronic inflammatory infiltrate (arrow). Bar=50 $\mu \mathrm{m}$. (B) Reactive (type C) gastritis. Prominent lamina propria smooth muscle fibres positive for bFGF (asterisk). Bar=100 $\mu \mathrm{m}$. 
Table 3 Comparison of bFGF concentrations and bFGF histology score in patients with gastric ulcer and non-ulcer controls

\begin{tabular}{lll}
\hline & Ulcer & Non-ulcer \\
\hline No of subjects & 10 & 8 \\
bFGF (pg/mg) & $9.6(2.8-16.4)$ & $257.1(139.8-374.4)$ \\
Total bFGF histology score & $7.5(3.5-10)^{\star}$ & $3(2.25-4)$ \\
Reactive gastritis score & $4.5(3.5-6) \dagger$ & $1(0.25-2)$ \\
\hline
\end{tabular}

bFGF concentrations are expressed as the geometric mean ( $95 \%$ confidence interval). bFGF histology scores and reactive gastritis scores are expressed as the median value (interquartile range). $\star \mathrm{p}=0.03$ compared with non-ulcer controls.

$+\mathrm{p}<0.01$ compared with non-ulcer controls.

Table 4 Patients with gastric ulcer and controls who underwent biopsy of the antrum for bFGF extraction

\begin{tabular}{lll}
\hline & Ulcer & Non-ulcer \\
\hline No of subjects & 15 & 12 \\
Mean (SEM) age (y) & $64(3)$ & $51(4.1)$ \\
Sex (M:F) & $5: 10$ & $5: 7$ \\
Smoker (\%) & $2(13)$ & $5(42)$ \\
NSAID use (\%) & $5(33)$ & $4(33)$ \\
H pylori infection & $5(4)^{\star}$ & $5(4)^{\star}$ \\
Acid suppressing drug treatment & $10(66)$ & $5(42)$ \\
$\quad(>4$ days) (\%) & & \\
\hline
\end{tabular}

* Figures in brackets are the numbers of $H$ pylori negative patients who were taking a proton pump inhibitor.

tions measured by ELISA in gastric ulcer patients in the absence of reduced immunohistochemical staining. Graded $\mathrm{NaCl}$ and heparin extraction of bFGF was performed on mucosa from 15 different patients with an active ulcer $(n=7)$ or a healed ulcer $(n=8)$ and 12 new control (non-ulcer) patients (table 4). The two groups were well matched except for age (nonulcer patients were younger) and for use of acid suppressing drugs (greater in ulcer patients).
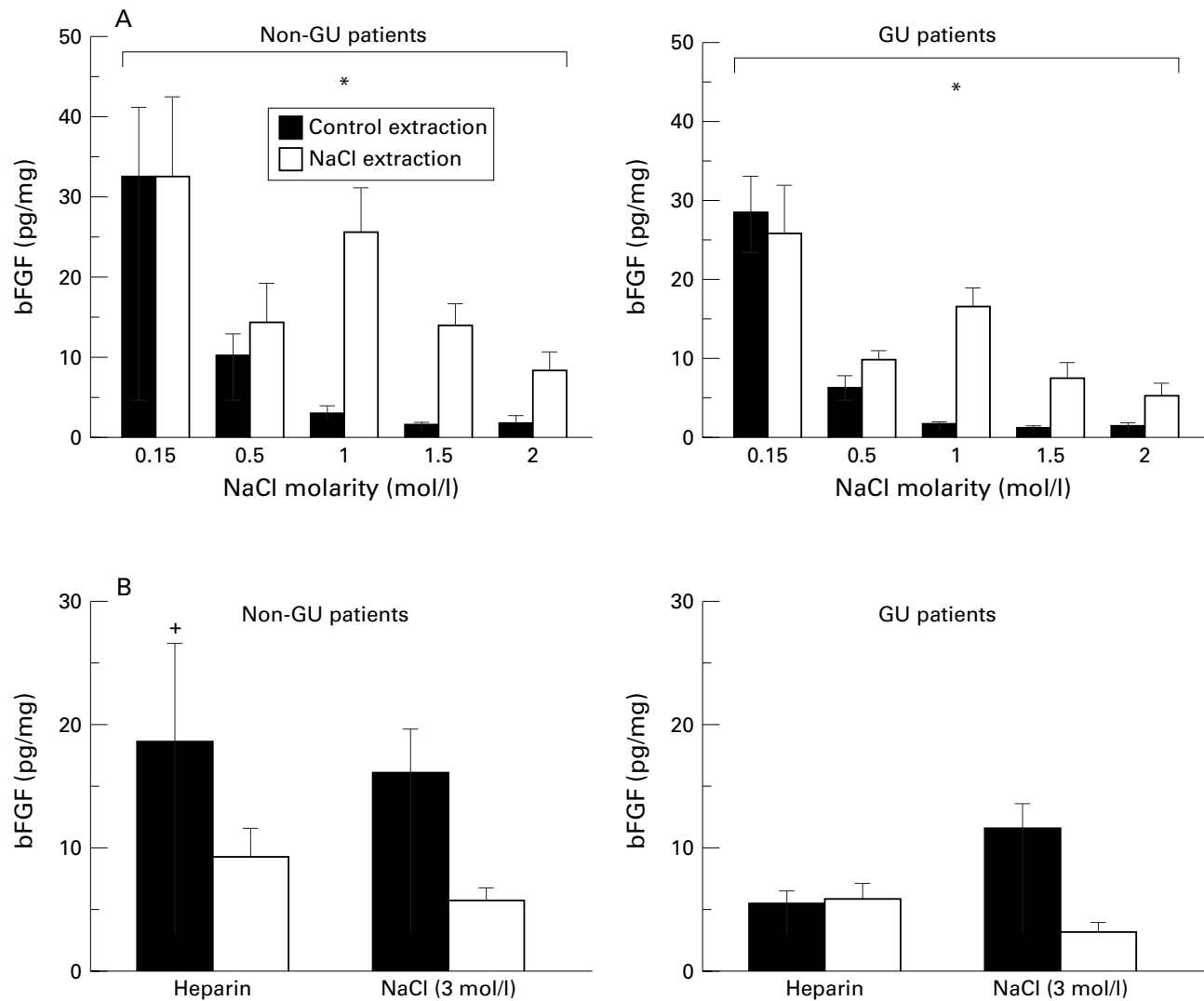

Four patients in each group were taking a proton pump inhibitor which did not allow accurate assessment of $H$ pylori status.

bFGF was extracted from antral mucosa in two peaks (fig 7A); $30 \%$ of total bFGF eluted at $0.15 \mathrm{~mol} / 1 \mathrm{NaCl}$ (peak 1) and $23 \%$ of total $\mathrm{bFGF}$ eluted at $1.0 \mathrm{~mol} / 1 \mathrm{NaCl}$ (peak 2) although bFGF continued to be extracted by 1.5 and $2.0 \mathrm{~mol} / 1 \mathrm{NaCl}$. Significantly more bFGF was eluted by graded $\mathrm{NaCl}$ extraction than repeated $0.15 \mathrm{~mol} / \mathrm{l} \mathrm{NaCl}$ extraction (mean 78.1 (SEM 10.8) pg/mg NaCl extraction versus 43.5 (5.2) $\mathrm{pg} / \mathrm{mg}$ control extraction, $\mathrm{p}<0.05$; fig 7A). Heparin and $3.0 \mathrm{~mol} / \mathrm{l} \mathrm{NaCl}$ extracted further bFGF from both $\mathrm{NaCl}$ and control extracted mucosa (fig 7B). More bFGF was released from control extracted mucosa by heparin and $3.0 \mathrm{~mol} / 1 \mathrm{NaCl}$ than $\mathrm{NaCl}$ extracted mucosa (fig 7B), presumably because of the limited bFGF extraction with repeated $0.15 \mathrm{~mol} / 1 \mathrm{NaCl}$ incubations which had taken place beforehand.

Total bFGF concentrations extracted by graded $\mathrm{NaCl}$ and heparin extraction were significantly lower in ulcer patients than non-ulcer controls (74.5 (8.7) pg/mg ulcer versus 109.5 (23.7) $\mathrm{pg} / \mathrm{mg}$ non-ulcer, $\mathrm{p}=0.02$ ). During $\mathrm{NaCl}$ and heparin elution, bFGF extracted from ulcer patients was consistently less at each molarity than in non-ulcer controls. However, there was no difference in the proportion of total bFGF which eluted at a particular $\mathrm{NaCl}$ molarity between ulcer and non-ulcer patients. After control extractions,

Figure 7 (A) bFGF extraction from antral mucosa of control (non-GU) and gastric ulcer (GU) patients by $\mathrm{NaCl}$. ${ }^{*}<<0.05$. (B) bFGF extraction from antral mucosa of non-GU and GU patients by $100 \mu \mathrm{g} / \mathrm{ml}$ heparin and $3.0 \mathrm{~mol} / \mathrm{l}$ $\mathrm{NaCl} .{ }^{+} \mathrm{p}=0.03$. 


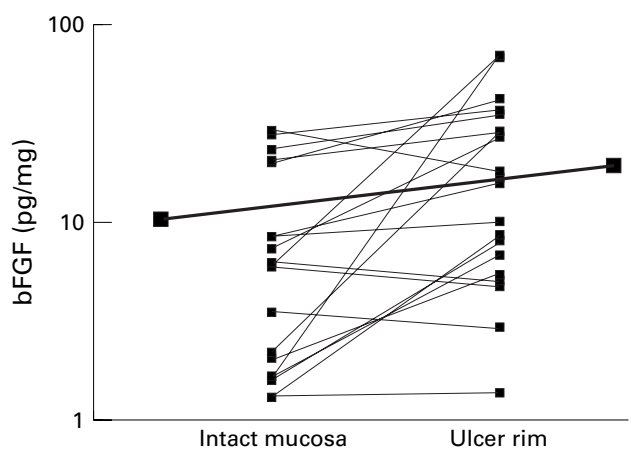

Figure 8 Increased bFGF concentrations at the rim of gastric ulcers compared with intact gastric mucosa. The thick line joins the mean values for the two groups. The thin lines join individual pairs of data.

heparin incubation with non-ulcer mucosa eluted significantly more bFGF than with mucosa from ulcer patients (18.7 (7.9) $\mathrm{pg} / \mathrm{mg}$ non-ulcer versus 5.8 (1.0) $\mathrm{pg} / \mathrm{mg}$ ulcer; $\mathrm{p}=0.03$; fig $7 \mathrm{~B}$ ). There was no difference in bFGF extracted by $0.15 \mathrm{~mol} / 1 \mathrm{NaCl}$ or total bFGF extracted between those patients with an active ulcer (3/7 taking acid suppressing drugs) and those with a healed ulcer ( $7 / 8$ taking acid suppressing drugs).

INDUCTION OF bFGF IN GASTRIC ULCERS bFGF concentrations were also measured in gastric mucosal homogenate supernatants obtained from the rim of 19 antral gastric ulcers and paired intact antral mucosa from 17 patients at endoscopy (table 1). bFGF concentrations at the ulcer rim were 2.2 (CI 1.2-4.0) fold higher than corresponding values in intact antral mucosa (fig 8). Induction of bFGF at the rim of $H$ pylori negative ulcers $(\mathrm{n}=11)$ was greater (3.3x increase (CI 1.2-8.9)) than at the rim of $H$ pylori positive ulcers $(\mathrm{n}=8 ; 1.2 \times$ increase (CI 0.8-1.9)). However, the difference
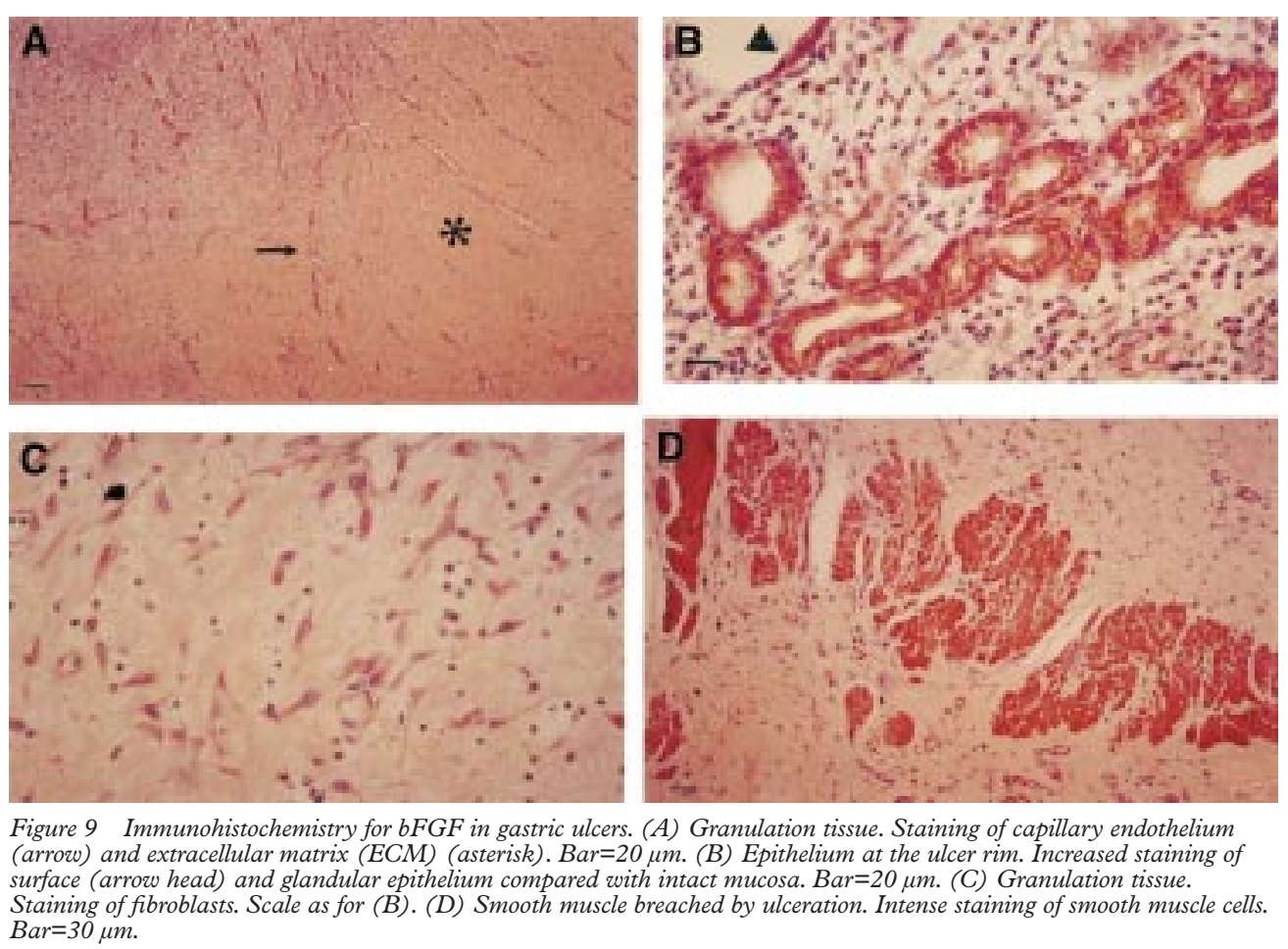

Figure 9 Immunohistochemistry for bFGF in gastric ulcers. (A) Granulation tissue. Staining of capillary endothelium (arrow) and extracellular matrix (ECM) (asterisk). Bar=20 $\mu \mathrm{m}$. (B) Epithelium at the ulcer rim. Increased staining of surface (arrow head) and glandular epithelium compared with intact mucosa. Bar=20 $\mu \mathrm{m}$. (C) Granulation tissue. Staining of fibroblasts. Scale as for (B). (D) Smooth muscle breached by ulceration. Intense staining of smooth muscle cells. Bar $=30 \mu m$.

in $\mathrm{bFGF}$ induction between $H$ pylori positive and negative ulcers just failed to reach statistical significance $(\mathrm{p}=0.059)$. Concentrations of $\mathrm{bFGF}$ at the rim of non-NSAID associated ulcers (mean 27.6 (CI 0-59.3) pg/mg, $\mathrm{n}=5$; diameter 5-35 $\mathrm{mm}$ ) were not significantly greater than values at the rim of NSAID associated ulcers (mean $16.2(5.2-27.2) \mathrm{pg} / \mathrm{mg}$, $\mathrm{n}=14$; diameter $4-20 \mathrm{~mm}$; $\mathrm{p}=0.6$ ).

LOCALISATION OF BFGF IN GASTRIC ULCERS Localisation of bFGF protein and $\mathrm{mRNA}$ was investigated in sections from nine chronic gastric ulcers. Mean (SEM) age of patients was 74 (2) years. Three patients were smokers and three patients were taking NSAIDs. Mean (SEM) ulcer diameter recorded in the operation notes was 12.5 (3) $\mathrm{mm}(\mathrm{n}=4)$. Two ulcers were described as "large". Ulcer size was not recorded in three cases. Ulcers were located as follows: three antrum, two incisura, four body. All ulcers were on the lesser curve.

\section{Immunohistochemistry}

Immunoreactive bFGF was localised to granulation tissue microvessels (fig 9A) and staining was also prominent in the extracellular matrix (ECM) of granulation tissue (fig 9A). A similar distribution of $\mathrm{bFGF}$ was seen in granulation tissue of all gastric ulcers examined. In seven of nine ulcers, there was increased immunostaining for bFGF in epithelial cells at the ulcer edge (fig 9B). In contrast to the distribution of bFGF in intact gastric epithelium, bFGF was localised to superficial epithelium including surface epithelial cells at the margin of the ulcer defect (fig 9B). There was also staining of granulation tissue fibroblasts (fig 9C). Muscularis mucosae and deeper smooth muscle fibres showed prominent bFGF staining especially when breached by ulcer granulation tissue (fig 


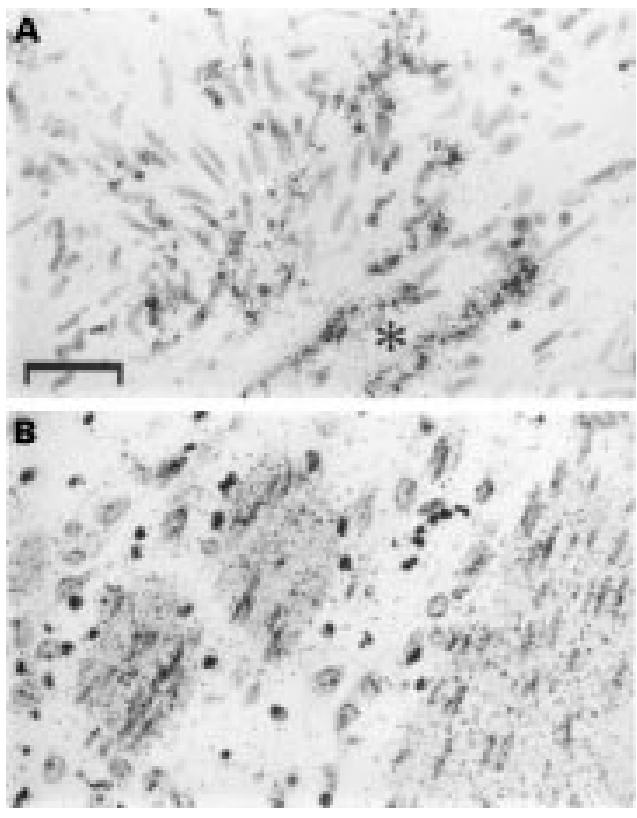

Figure 10 In situ hybridisation of $b F G F m R N A$ with a $450 b p{ }^{35} S$ labelled cDNA probe. (A) Gastric ulcer granulation tissue. Signal over mononuclear cells and endothelial cells of a capillary (asterisk). Bar=40 $\mu \mathrm{m}$. (B) Gastric ulcer. Signal over smooth muscle cells breached by ulcer granulation tissue.

9D). There was no obvious qualitative difference in bFGF immunoreactivity between NSAID and non-NSAID associated gastric ulcers.

In situ hybridisation

There was hybridisation of the bFGF probe with bFGF mRNA over granulation tissue microvessel endothelial cells, fibroblasts, and macrophages (fig 10A). There was signal localisation in the muscle layer of arterioles and over smooth muscle fibres surrounded by granulation tissue (fig 10B). There was no evidence of bFGF mRNA localisation in epithelial cells near the ulcer rim despite the immunohistochemical findings.

\section{Discussion}

In these studies we have characterised bFGF expression in normal human gastric mucosa by a number of techniques including heparin affinity chromatography, ELISA, bioassay, and immunohistochemistry. The size $(19 \mathrm{kDa})$ and elution profile from heparin of gastric mucosal $\mathrm{bFGF}$ is in keeping with previous reports of bFGF isolation from several tissues, including a gastric carcinoma resection specimen. ${ }^{4}{ }^{13}{ }^{19-29}$ In keeping with other studies, there was no evidence of high molecular weight $\mathrm{bFGF}^{30}$ in gastric mucosa when assessed by western blot analysis. The $19 \mathrm{kDa}$ bFGF is likely to be the full 154 amino acid protein predicted by cloning of the human bFGF gene. ${ }^{20}$ The cocktail of protease inhibitors used during initial protein extraction seems to have prevented the formation of any $\mathrm{N}$-terminal truncated forms of bFGF present in other studies. ${ }^{20}$ We also used a gastric endothelial cell proliferation assay which confirmed that gastric mucosal bFGF had physiologically relevant bioactivity similar to authentic bFGF. ${ }^{12}$
The immunohistochemical studies revealed immunoreactive bFGF in endothelial cells, smooth muscle cells, and ECM. These findings are consistent with previous immunohistochemical studies of other human tissues ${ }^{5} 6291$ and data showing that endothelial cells can synthesise bFGF in vitro. ${ }^{32}$ Diffuse staining of ECM may represent bFGF sequestered by extracellular HSPGs. Our studies showed patchy staining of epithelial cells; existing data regarding epithelial bFGF expression are conflicting. One study did not detect bFGF in epithelium $^{5}$ while another showed staining of epithelial basement membranes. ${ }^{6}$ Others have shown cytoplasmic staining in normal epithelium $^{33}$ and gastric carcinoma cells. ${ }^{34}$

Our inability to show bFGF mRNA in normal gastric mucosa by northern blot analysis or in situ hybridisation suggests that we detected stored bFGF which had been synthesised previously. This finding is in keeping with data from a variety of animal tissues which suggest that bFGF mRNA synthesis in normal tissues occurs at a very low level. ${ }^{35}{ }^{36}$ bFGF is likely to be synthesised by gastric mucosal cells at a low concentration and then stored in association with mucosal HSPGs in an inactive state ready for future mobilisation. ${ }^{9}$

The most striking finding of our study was the dramatic reduction in intact antral mucosal bFGF concentrations measured by ELISA in gastric ulcer patients. This could not be accounted for by differences between ulcer and non-ulcer patient demographic data and was not explained by NSAID use, $H$ pylori status, or presence of gastritis. We initially used a simple bFGF extraction technique with recovery of bFGF into $0.15 \mathrm{~mol} / 1 \mathrm{NaCl}$. This left open the possibility that the apparent reduction in bFGF concentrations in gastric ulcer patients might have arisen spuriously as a result of more avid binding to mucosa of similar amounts of bFGF (which could also account for increased immunohistochemical staining in these patients). However the $\mathrm{NaCl}$ and heparin extraction experiments confirmed that gastric ulcer patients had a true reduction in intact antral mucosal bFGF compared with non-ulcer controls and that there were no alterations in bFGF elution profile to suggest differences in strength of binding of bFGF to gastric mucosal HSPGs. The greater degree of reactive gastritis (and superficial lamina propria muscle bFGF staining) in the small subset of gastric ulcer patients which underwent bFGF histological analysis probably explains the paradoxical increase in immunohistochemical staining despite low bFGF concentrations measurable by ELISA. We have also shown that acid suppressing drugs increase intact mucosal bFGF concentrations. However this effect was smaller in magnitude than the depression in bFGF concentrations seen in gastric ulcer compared with control patients. This is likely to be due to protection of acid labile bFGF from luminal acid. ${ }^{4}$ Our data are consistent with the only other study in which gastric mucosal bFGF concentrations have been measured in humans by ELISA. ${ }^{37}$

Approximately one third of extractable mucosal bFGF was released by incubation 
with $0.15 \mathrm{~mol} / 1 \mathrm{NaCl}$. Basic FGF released in this manner may not be bound to HSPGs and may have been released by mechanical trauma alone. Alternatively, a fraction of bFGF bound to HSPGs could have been released by mucosal heparitinases activated by homogenisation. Further mucosal bFGF was released by increasing $\mathrm{NaCl}$ molarity which peaked at 1.0 $\mathrm{mol} / \mathrm{l} \mathrm{NaCl}$. The very low concentrations of bFGF extracted by control elution confirmed that release of bFGF was related to increasing $\mathrm{NaCl}$ molarity. The profile of bFGF elution from gastric mucosa reported here is consistent with reports in the literature by workers who have investigated elution of HSPGs from immobilised bFGF $^{9839}$ and is further evidence that HSPGs bind bFGF in human gastric mucosa. Thus, there appears to be two pools of gastric mucosal bFGF: "free" bFGF which is not bound to HSPGs and which can be released by mechanical perturbation; and "bound" bFGF which is bound to HSPGs and is eluted by $0.5-3.0 \mathrm{~mol} / 1 \mathrm{NaCl}$ and heparin. Increased extraction of bFGF from mucosa of non-ulcer patients by heparin would suggest that the excess bFGF in these patients is "bound" bFGF. The absolute bFGF concentrations extracted by $0.15 \mathrm{~mol} / 1 \mathrm{NaCl}$ during the $\mathrm{NaCl}$ and heparin extraction experiments were lower than those obtained in the initial extraction experiments. This could be explained by degradation of bFGF during the 10 minute incubation period before centrifugation or by absorption of bFGF during gel filtration in the extraction experiments.

Reduced mucosal bFGF content could be explained by decreased bFGF synthesis, increased bFGF degradation, or both. Even if bFGF synthesis in intact gastric mucosa is very low, reduced bFGF synthesis over a long period of time could account for reduced mucosal bFGF content if the bFGF degradation rate remained constant. Increased degradation of mucosal bFGF is more likely to account for reduced mucosal bFGF concentrations. As bFGF is very acid labile, back diffusion of luminal acid into superficial mucosa could destroy significant amounts of mucosal bFGF. It has been calculated that net flux of $\mathrm{H}^{+}$from lumen to mucosa occurs in the normal human stomach (1-2 mEq/15 minutes) which is increased after instillation of an acid load. ${ }^{40}{ }^{41}$ Increased acid back diffusion has previously been noted in gastric ulcer patients before and after healing. ${ }^{42}$ Although $H$ pylori and NSAIDs have the potential to increase acid back diffusion, our studies did not identify either as a significant factor in determining mucosal bFGF concentrations.

The presence of a fibroblast growth factor binding protein (FGF-BP) in human gastric mucosa could provide an alternative explanation for the ELISA and immunohistochemistry data obtained in this study. A secreted FGF-BP, which mobilises and activates locally stored bFGF in vitro, ${ }^{43}$ has recently been shown to play an important role in squamous cell carcinoma growth and angiogenesis. ${ }^{44}$ If FGF-BP binding to bFGF in gastric mucosa involved the bFGF epitopes which are recognised by Mab52 and
Mab98, then altered expression of FGF-BP could account for the differences in measurable bFGF concentrations between gastric ulcer patients and controls and also the paradoxical ELISA and immunohistochemistry data.

Against a background of low bFGF concentrations, expression of bFGF was increased in gastric ulcers. Our immunohistochemistry and in situ hybridisation studies showed bFGF expression by microvessel endothelial cells, mononuclear cells, and fibroblasts in granulation tissue. Capillary endothelial cells and macrophages have previously been shown to synthesise bFGF in culture ${ }^{32} 45$ and bFGF has previously been noted in granulation tissue fibroblasts and macrophages in gastric ulcers in animals ${ }^{146}$ and humans. ${ }^{47}$ bFGF immunoreactivity was prominent in muscle especially if this layer was breached by an ulcer. Muscle fibres could act as an intracellular store of bFGF for release if tissue injury becomes deep enough to cause damage to this layer. We showed bFGF protein in epithelial cells at the rim of ulcers. Induction of bFGF synthesis may be analogous to up regulation of EGF synthesis at the edge of chronic ulcers. ${ }^{48}$ However, increased bFGF mRNA could not be detected in epithelial cells by in situ hybridisation. This discrepancy suggests that induction of bFGF mRNA synthesis may be an early event after gastric mucosal injury, as has been reported in rats ${ }^{49}$ and that the peak of bFGF synthesis was missed in the surgically resected gastric ulcers examined in this study. Further studies of bFGF mRNA expression in gastric ulcers by reverse transcriptase polymerase chain reaction (RT-PCR) and in situ PCR are required to determine whether there is an increase in bFGF mRNA synthesis in epithelial cells at the ulcer rim. Alternatively, epithelial cells could have taken up bFGF released from ECM after digestion of HSPGs by granulation tissue heparanases. This hypothesis could be tested by incubation of isolated gastric epithelial cells with exogenous bFGF followed by demonstration of intracellular accumulation of bFGF by subcellular fractionation techniques. Epithelial cell bFGF could play a role in angiogenesis in adjacent granulation tissue or have actions on ulcer rim epithelium. There is evidence that bFGF promotes frog gastric epithelial cell restitution in vitro ${ }^{50}$ and restitution of rat intestinal epithelial cells in culture. ${ }^{51}$

The increase in bFGF concentrations at the ulcer rim was smaller than the reduction of bFGF in intact mucosa compared with nonulcer patients. These data are also consistent with the study by Tsuji et al. ${ }^{37}$

There was a trend towards decreased ulcer rim bFGF concentrations in $H$ pylori positive gastric ulcers compared with $H$ pylori negative ulcers. This was not explained by differences in NSAID use between the two groups. The lack of statistical significance could have been caused by type II error and more ulcers need to be studied. Two mechanisms by which the presence of $H$ pylori could reduce bFGF concentrations could be implicated: $H$ pylori lysates contain protease activity which reduces bFGF induced mitogenic activity ${ }^{52}$, and $H$ 
pylori expresses cell surface HSPGs which bind bFGF avidly and could sequester mucosal bFGF $^{53}$ Decreased induction of bFGF in NSAID associated gastric ulcers was not shown and does not account for the impaired angiogenic response in such ulcers. ${ }^{54}$

In summary, bFGF is present in normal human gastric mucosa and its expression is up regulated in gastric ulcers. Gastric ulcer patients appear to have a constitutional deficiency of mucosal bFGF which is not explained by altered binding by gastric mucosal HSPGs. Further experiments are required to test the hypothesis that reduced mucosal bFGF content predisposes to ulcer formation.

J L Brough was supported by a grant from the Trent Research Scheme. Part of this work has been presented to the American Gastroenterological Association in abstract form (Gastroenterology 1994;106:A97; Gastroenterology 1995;108:A117). The auogy 1994;106:A97; Gastroenterology 1995;108:A117). The authors wish to thank Professor John T Gallagher, Christie Hospiexperiments.

1 Satoh H, Shino A, Sato F, et al. Role of endogenous and exogenous bFGF in the healing of gastric ulcers in the rat [abstract]. Gastroenterology 1992;102:A159.

2 Szabo S, Folkman J, Vattay P, et al. Accelerated healing of duodenal ulcers by oral administration of a mutein of basic fibroblast growth factor in rats. Gastroenterology 1994;106: fibroblast

3 Hull MA, Cullen DJE, Hudson N, et al. Basic fibroblast growth factor treatment for non-steroidal antigrowth factor treatment for non-steroidal antiinflammatory

4 Folkman J, Szabo S, Stovroff M, et al. Duodenal ulcer. Discovery of a new mechanism and development of angiogenic therapy that accelerates healing. Ann Surg 1991;214:41427.

5 Hughes SE, Hall PA. Immunolocalization of fibroblast growth factor receptor 1 and its ligands in human tissues. Lab Invest 1993;69:173-82.

6 Ernst H, Muller M, Paulus A, et al. Immunohistochemical localization of basic fibroblast growth factor in the norma adult gastrointestinal tract. Eur 7 Gastroenterol Hepatol 1994;6:559-64.

7 Yayon A, Klagsbrun M, Esko J, et al. Cell surface, heparinlike molecules are required for the binding of basic fibroblast growth factor to its high affinity receptor. Cell 1991;64:841-8.

8 Saksela O, Moscatelli D, Sommer A, et al. Endothelial cellderived heparan sulphate binds basic fibroblast growth factor and protects it from proteolytic degradation. 7 Cell Biol tor and protects it

9 Vlodavsky I, Fuks Z, Ishai-Michaeli R, et al. Extracellular matrix-resident basic fibroblast growth factor: implication
for the control of angiogenesis. F Cell Biochem 1991;45: for the $167-76$.

10 Watanabe H, Hori A, Seno M, et al. A sensitive enzyme immunoassay for human basic fibroblast growth factor. Biochem Biophys Res Commun 1991;175:229-35.

11 Hori A, Sasada R, Matsutani E, et al. Suppression of solid tumor growth by immunoneutralizing monoclonal antibody against human basic fibroblast growth factor. Cancer Res 1991;51:6180-4.

12 Hull MA, Hewett PW, Brough JL, et al. Isolation and culture of human gastric endothelial cells. Gastroenterology 1996; 111:1230-40.

13 Gonzalez A-M, Buscaglia M, Fox R, et al. Basic fibroblast growth factor in Dupytren's contracture. Am f Pathol growth factor in

14 Iwane M, Kurokawa T, Sasada R, et al. Expression of cDNA encoding human basic fibroblast growth factor in E. coli. Biochem Biophys Res Commun 1987;146:470-7.

15 Chomczynski P, Sacchi N. Single-step method of RNA isolation by acid guanidium thiocyanate-phenol-chloroform extraction. Anal Biochem 1987;162:156-9.

16 Sandberg M, Vuorio E. Localization of types I, II and III collagen mRNAs in developing human skeletal muscle tissues by in situ hybridization. F Cell Biol 1987;104:1077-84

17 Berndt A, Kosmehl H, Mandel U, et al. TGF $\beta$ and bFGF synthesis and localization in Dupytren's disease (nodular palmar fibromatosis) relative to cellular activity, myofibroblast phenotype and oncofetal variants of fibronectin. Histochem 7 1995;27:1014-20

18 Bikfalvi A, Alterio J, Inyang AL, et al. Basic fibroblast growth factor expression in human omental microvascular endothelial cells and the effect of phorbol ester. $\mathcal{F}$ Cell Physiol 1990;144:151-8.

19 Gospodarowicz D, Cheng J, Lui G-M, et al. Isolation of brain fibroblast growth factor by heparin-sepharose affinity
chromatography: identity with pituitary fibroblast growth factor. Proc Natl Acad Sci USA 1984;81:6963-7.
20 Ueno N, Baird A, Esch F, et al. Isolation of an amino termial extended form of basic fibroblast growth factor. Biochem Biophys Res Commun 1986;138:580-8.

21 DiMario J, Buffinger N, Yamada S, et al. Fibroblast growth factor in the extracellular matrix of dystrophic (mdx) mouse muscle. Science 1989;244:688-90.

22 Shing Y, Folkman J, Sullivan R, et al. Heparin affinity: purification of a tumor-derived capillary endothelial cell growth factor. Science 1984;223:1296-9.

23 Gospodarowicz D, Cheng J, Lui G-M, et al. Corpus luteum angiogenic factor is related to fibroblast growth factor. Endocrinology 1985;117:2383-91.

24 Klagsbrun M, Shing Y. Heparin affinity of anionic and cationic capillary endothelial cell growth factors: analysis of hypothalamus-derived growth factors and fibroblast growth factors. Proc Natl Acad Sci USA 1985;82:805-9.

25 Lobb R, Sasse J, Sullivan R, et al. Purification and characterization of heparin-binding endothelial cell growth factors. F Biol Chem 1996;261:1924-8.

26 Presta M, Moscatelli D, Joseph-Silverstein J, et al. Purification from a human hepatoma cell line of a basic fibroblast growth factor-like molecule that stimulates capillary endothelial cell plasminogen activator production, DNA synthesis and migration. Mol Cell Biol 1986;6:4060-6.

27 Baird A, Esch F, Mormede P, et al. Molecular characterization of fibroblast growth factor: distribution and biological activities in various tissues. Recent Prog Horm Res 1986;42: 143-205.

28 Joseph-Silverstein J, Consigli SA, et al. Basic fibroblast growth factor in the chick embryo: immunolocalization to striated muscle cells and their precursors. F Cell Biol 1989; 108:2459-66.

29 Cordon-Cardo C, Vlodavsky I, Haimovitz-Friedman A, et al. Expression of basic fibroblast growth factor in normal human tissues. Lab Invest 1990;63:832-40.

30 Florkiewicz RZ, Sommer A. Human basic fibroblast growth factor gene encodes four polypeptides: three initiate translation from non-AUG codons. Proc Natl Acad Sci USA 1989;86:3978-81

31 Schulze-Osthoff K, Risau W, Vollmer E, et al. In situ detection of basic fibroblast growth factor by highly specific antibodies. Am f Pathol 1990;137:85-92.

32 Schweigerer L, Neufeld G, Friedman J, et al. Capillary endothelial cells express basic fibroblast growth factor, a mitogen that promotes their own growth. Nature 1987;325: 257-9.

33 Bordi C, Falchetti A, Buffa R, et al. Production of basic fibroblast growth factor by gastric carcinoid tumors and their putative cells of origin. Hum Pathol 1994;25:175-80.

34 Ueki T, Koji T, Tamiya S, et al. Expression of basic fibroblast growth factor and fibroblast growth factor receptor in advanced gastric cancer. F Pathol 1995;177:353-61

35 Shimasaki S, Emoto N, Koba A, et al. Complementary DNA cloning and sequencing of rat ovarian basic fibroblast growth factor and tissue distribution study of its mRNA. Biochem Biophys Res Commun 1988;157:256-63.

36 Baird A, Bohlen P. Fibroblast growth factors. In: Sporn MB, Roberts $\mathrm{AB}$, eds. Peptide growth factors and their receptors $I$. New York: Springer-Verlag, 1990:369-418.

37 Tsuji S, Kawano S, Higashi T, et al. Gastric ulcer healing and basic fibroblast growth factor: effects of lansoprazole and famotidine. 7 Clin Gastroenterol 1995;20(suppl 2):S1-4.

38 Turnbull JE, Fernig D, Ke Y, et al . Identification of the basic FGF binding sequence in fibroblast heparan sulphate. $\mathcal{F}$ Biol Chem 1992;267:10337-41.

39 Habuchi H, Suzuki S, Saito T, et al. Structure of a heparan sulphate oligosaccharide that binds to basic fibroblast growth factor. Biochem $\mathcal{F}$ 1992;285:805-13.

40 Chapman MA, Werther JL, Janowitz HD. Response of the normal and pathological human gastric mucosa to an instilled acid load. Gastroenterology 1968;55:344-53

41 Ivey KJ, DenBesten L, Clifton JA. Effect of bile salts on ionic movement across the human gastric mucosa. Gastroenterology 1970;59:683-90.

42 Hossenbocus A, Fitzpatrick P, Colin-Jones DG. Potential difference across the normal and the abnormal gastric mucosa in man. Gut 1976;17:993-7.

43 Czubayko F, Smith RV, Chung HC, et al. Tumor growth and angiogenesis induced by a secreted binding protein for fibroblast growth factors. F Biol Chem 1994;45:28243-8.

44 Czubayko F, Liaudet-Coopman EDE, Aigner A, et al. A secreted FGF-binding protein can serve as the angiogenic switch in human cancer. Nat Med 1997;3:1137-40.

45 Baird A, Mormede P, Bohlen P. Immunoreactive fibroblast growth factor in cells of peritoneal exudate suggests its identity with macrophage-derived growth factor. Biochem Biophys Res Commun 1985;126:358-64.

46 Yabu M, Shinomura Y, Minami T, et al. Immunohistochemical localization of basic fibroblast growth factor in the healing stage of mouse gastric ulcer. Histochemistry 1993; 100:409-13.

7 Ohtani H, Nakamura S, Watanabe Y, et al. Immunocytochemical localization of basic fibroblast growth factor in carcinomas and inflammatory lesions of the human digestive tract. Lab Invest 1993;68:520-7.

48 Wright NA, Pike C, Elia G. Induction of a novel epidermal growth factor-secreting cell lineage by mucosal ulceration in human gastrointestinal stem cells. Nature 1990;343:82-5.

49 Florkiewicz RZ, Santos A, Tanoue K, et al. Gastric mucosal injury stimulates bFGF and its receptor gene expression $\mathrm{kDa}$ isoforms [abstract]. Gastroenterology 1995;108:A725. 
50 Paimela H, Goddard PJ, Carter K, et al. Restitution of frog gastric mucosa in vitro: effect of basic fibroblast growth factor. Gastroenterology 1993;104:1337-45.

51 Dignass AU, Tsunekawa S, Podolsky DK. Fibroblast growth factors modulate intestinal epithelial cell growth and migration. Gastroenterology 1994;106:1254-62.

52 Szabo S, Shing Y, Fox J, et al. Inactivation of basic fibroblast growth factor (bFGF) by gastric helicobacters and not by E. coli [abstract]. Gastroenterology 1994;106:A190.

53 Ascencio F, Hansson HA, Larm O, et al. Helicobacter pylori interacts with heparin and heparin-dependent growth factors. FEMS Immunol Med Microbiol 1995;12:265-72.

54 Hudson N, Balsitis M, Everitt S, et al. Angiogenesis in gastric ulcers; impaired in patients taking non-steroidal anti-inflammatory drugs. Gut 1995;37:191-4.

\section{A national register of $\mathrm{HCV}$ infections with a known date of acquisition}

\section{A call for study proposals}

A national register of hepatitis $\mathrm{C}$ virus (HCV) infections with a known date of acquisition is being established, and infections that have been acquired through transfusion of blood or blood components will form the nucleus of the register. It is hoped that the register will provide a national resource for researchers and clinicians alike, and a number of future studies can be envisaged which would benefit from linkage with, and access to, the register.

Mandatory screening of blood donations for antibodies to HCV was introduced by the National Blood Transfusion Service in the United Kingdom in September 1991. ${ }^{1}$ As a result, a number of anti-HCV positive donors were identified some of whom had donated blood before the introduction of screening. In early 1995, the UK Health Departments announced that a "look back" at recipients of blood or blood components derived from anti-HCV positive donors would be undertaken. ${ }^{2}$ A high proportion of the recipients of $\mathrm{HCV}$ infected blood are expected to be infected with $\mathrm{HCV},{ }^{3}$ and although most are likely to be asymptomatic in the early stages of infection, ${ }^{4}$ all infected recipients are being referred to clinicians with an interest in hepatic disease for assessment and clinical follow up.

Cases of HCV infection acquired by transfusion and identified by the "look back" are unusual in having a known date of acquisition, an identifiable source, and in having been diagnosed relatively early in the course of infection. Although few in number, the register will be extended to cover other infections of known date, such as documented seroconversions and occupational exposures. Documented seroconversions will include those individuals with virologically confirmed $\mathrm{HCV}$ infection for whom a reliable negative result of a test of the same type for $\mathrm{HCV}$ infection has been recorded at any point in the preceding four years. The register therefore provides a unique opportunity to monitor incubation period distribution from infection to disease and death, and to provide a group of $\mathrm{HCV}$ infections with a known date of acquisition as a resource for other studies.

All clinicians responsible for the care of eligible subjects will be invited to register their patients, and assistance with completion of forms will be available for those clinicians caring for a number of eligible patients. Information on each patient's current clinical status, test results, treatment and management will be gathered using a standard report form, and clinicians responsible for the continuing care of registered patients will be invited to complete and return follow up forms annually on each patient. Such information is urgently needed to help determine the current and future burden of hepatitis $\mathrm{C}$ related disease on health care services, and to assess the impact of currently available treatments and those which may become available in the future.

Any researchers interested in applying for access to information held within the national register should contact the register coordinator (details below) for a list of available data. Any study proposals should then be submitted to the register coordinator for consideration by the steering group by 6 November 1998. It is envisaged that the register will provide a national resource that could assist researchers in studies of sexual, vertical and household transmission; clinical trials of new antiviral drugs; further evaluation of existing antivirals and of alternative treatment protocols; determination of the relations between viral load, genotype, treatment and disease progression; and studies of markers prognostic for progression to disease.

NATIONAL HCV REGISTER STEERING GROUP:

M RAMSEY

G ALEXANDER

A ROBINSON

V JAMES

H NICHOLAS

J HEPTONSTALL

Correspondence to: Dr Helen Harris (Register Coordinator): Immunisation Division, Communicable Disease

Surveillance Centre, Public Health Laboratory Service, 61 Colindale Avenue, London NW9 6EQ, UK. Tel: 0181200

6868 ext.4676; Fax: 0181200 7868; Email: hharris@phls.co.uk.

1 CDSC. Hepatitis C and blood transfusion. Commun Dis Rep CDR Wkly 1995;5:9.

2 Department of Health. Hepatitis C and blood transfusion look back. London: HMSO, 1995 [PL CMO(95)1]

3 Ayob Y, Davidson JI, Baxter A, et al. Risk of hepatitis C in patients who received blood from donors subsequently shown to be carriers of hepatitis C virus. Transfus Med 1994;4:269-72.

4 Seeff LB. Natural History of Hepatitis C. Hepatology 1997;26(suppl 1):21S-8S. 